\title{
Crises of European Integration: A Downward Spiral or Productive Crises?
}

\section{Hartmut KAELBLE}

The European Union has been mired in a serious crisis since 2008. While the most acute phase appears to have been overcome, it still remains to be seen whether an erroneous decision by the European Council or a national European government, the collapse of a large bank or violent conflicts within a member state may trigger its return. This crisis was not merely an ill-fated conflation of financial crisis, a steep decline in economic growth and mounting national debt. It was also a severe crisis of European integration, a dramatic challenge for decision-makers in the European Council, European Central Bank and European Commission, a period of unusual tensions between the Northern and Southern member state of the European Union, a deep crisis of confidence among the citizenry and a global loss of confidence in the European Union. In the light of the current grey area between a latent susceptibility for further crises down the road and a crisis which appears to have subsided but whose presence still lingers, it makes sense to integrate this crisis into the long history of the crises of European integration and ask what was repeated in this particular crisis and what was new about it.

Three very different historical interpretations of the crises of European integration were invoked in the midst of this crisis and they also came to be employed in the political debates. As a rule, these interpretations had already been subject to debate in earlier crises of European integration, yet they gained particular currency during the acute phase of the current crisis. While I intend to use these three narratives as a point of departure, the history of this debate in politics and the sciences does not form part of this inquiry.

A first group of observers and decision makers feared - or in some instances hoped - that these crises of European integration would become exacerbated in a downward spiral and that Europe might be on the verge of a final crisis, a collapse of its currency, or even of the European Union itself. Some papers explored various scenarios of the collapse, and of European politics after the European Union, usually as a cautionary warning of a possible collapse, but sometimes also with hopes for an end to the European Union in its present form, and with a welcome return to national political sovereignty. A second group of observers continued to believe in the idea of a productive crises of European integration, even in the midst of this serious crisis. According to this well-established notion, crises of European integration in the past have regularly led to progress when it came to further integration. Moreover, in the light of all historical experience, they argue that European integration even required crises of this sort in order to move ahead. In this view, crises of European integration were productive ones. Further steps towards integration are expected in the wake of the current crisis, such as stricter European controls of national budgets and the European banking system. Finally, a third, cyclical interpretation is also recorder, 
which asserts that serious crises of European integration occur every thirty to forty years. Every generation of European politicians is said to experience its own serious European crisis and will seek to find its own solutions. Deep-seated crises are sometimes seen as evidence for the failure of the European policies of preceding generations and, simultaneously, the beginning of new policies pursued by a new generation.

Surprisingly, past crises of European integration have not been examined in their entirety for the purpose of determining whether they amounted to a downward spiral, whether they helped advance European integration, or if they developed cyclically instead. However, individual European crises have been thoroughly researched by both historians and political scientists, and this is particular true for the crises in the 1950s and 1960s. ${ }^{1}$ Furthermore, an interesting debate surrounding the decline in support for the EuropeanUnionamong the public began to take shape in the political sciences from 1990

1. P.BAJON,Europapolitik,, am Abgrund“. Die Krise des ,,leeren Stuhls “1965-66, FranzSteinerVerlag, Stuttgart, 2012; D. DINAN, Ending the Constitutional Impasse, in: Journal of Common Market Studies, vol.46, (2008), pp.71-90; D. DINAN, Governance and Institutions: Implementing the Lisbon Treaty in the Shadow of the Euro Crisis, in:Journal of Common Market Studies, 49(September2011),pp.103-121; R. FRANK, La construction européenne, une histoire cyclique, in: Questions internationales, 7(2004), pp.6-21; R. FRANK, Vers un traité refondateur, in: M.-T. Bitsch(ed.), Cinquante ans de traité de Rome 1957-2007, Franz Steiner Verlag, Stuttgart, 2009, pp.75-95; M. GEHLER, From Crisis to Crisis, from Success to Success? European Integration Challenges and Opportunities in Light of Europe's History (1918-2009), in: M. GEHLER, X. GU, A. SCHIMMELPFENNIG(eds), EUChina. Global Players in a Complex World, in: Historische Europa-Studien, 6(2012), pp.45-74; H. KAELBLE, Die Krise in der Europäischen Unionaus historischer Sicht, in:Zeitschrift für Staats-und Europawissenschaft, 3(2005), pp.522-554;H.KAELBLE, EuropainderKrise.Zivilisationskrise-Integrationskrise-Krisenmanagement, in: T.Mergel (ed.), Krisen verstehen: Historische und kulturwissenschaftliche Annäherungen, Campus Verlag, Frankfurt a.M., 2012, pp.131-144; S. KAHN, Histoire de la construction de l'Europe depuis 1945, PUF, Paris, 2011; P. LAGROU, La crise européenne, in: P. MAGNETTE, A. WEYEMBERGH(eds), L'Unioneuropéenne, lafind'unecrise?,Éd. del'Universitéde Bruxelles, Brussels, 2008, pp.15-24; R. KIRT (ed.), Die Europäische Union und ihre Krisen, Nomos, Baden-Baden, 2001; L. KÜHNHARDT (ed.), Crises in European Integration. Challenges and Responses, 1945-2005, Berghahn Books, New York/Oxford, 2009; W. LOTH (ed.), Crisis and Compromises, the European project 1963-1969, Nomos, Baden-Baden, 2001; N.P. LUDLOW (ed.), The European Community and the crisis of the 1960's. Negotiating the Gaullist Challenge, Routledge, London, 2005; J.M.PALAYRET,H.WALLACE,P.WINAND(eds.),Visions, votesandvetos. Theemptychaircrisisand the Luxemburgcompromisefortyyearson, European Interuniversity Press, Brussels, 2006; H. SCHULZFORBERG, On the historical origins of the EU's current crisis: Or, the hypocritical turn of European integration, in: A.J.MENÉNDEZ,E.CHITI,P.TEIXEIRA(eds), TheEuropean Rescueof the European Union? The ExistentialCrisisoftheEuropeanPoliticalProject, in:ReconReport, 19(2012),pp.15-36;H. SCHULZ-FORBERG, B. STRATH, Soft and Strong European Public Spheres, in: R. FRANK, H. KAELBLE, M.-F.LÉVY,L.PASSERINI(eds), Building a European Public Sphere: From the 1950s to the Present, Peter Lang, Brussels, 2010, pp.55-76; A. VARSORI (ed.), Alle origini del presente. L'Europa occidentale nella crisi degli anni settanta, Franco Angeli, Milan, 2007. 
onwards. ${ }^{2}$ Beyond this, we can say that the numerous historical syntheses of European integration have, between them, yielded a catalogue of eight crises of European integration: 1) The European crisis after the Second World War from 1945 to 1951;2) the crisis following the rejection of the European Defence Community by the French parliament in 1954;3) the empty chair crisis 1965/66;4) the failure of plans for an economic and currency union and the political union in the early 1970s, and the subsequent eurosclerosis in the early 1980s; 5) the crisis in the wake of German unification in 1990, followed by the Maastricht Treaty's crisis of ratification in 1992; 6) the parallel European crisis in the wake of the Yugoslavian Civil War 1991-1995; 7) the rejection of the European constitution by France and the Netherlands in 2005; 8) finally, the debt crisis since 2010, preceded by the financial crisis since 2008, in the US since 2007. Indeed, one may also view the different crises in the early 1990s as one single, albeit very complex crisis. ${ }^{3}$ Accordingly, this would amount to seven crises of European integration. Onecan merely speculate as to why a systematic historical examination of these crises has notyet been carried out.

This short essay will initially attempt a typology of the previous crises of European integration, followed by a closer examination of the above-mentioned notions of a downward spiral, productive crises and historical crisis cycles on the basis of this typology in an attempt to determine which of these differing conceptions best represents the history of the crisis of European integration.

2. R.C.EICHENBERG, R.J.DALTON, Post-Maastricht blues: The transformation of citizen supportfor European integration 1973-2004, in: Actapolitica, 42(2007),pp.128-152;L. HOOGHE, G. MARKS, A postfunctional theory of European integration: frompermissive consensus toconstraining dissensus, in: British Journal of Political Science, 1(2009), pp.1-24; D. FUCHS, C. SCHNEIDER, Support of the EU and European identity, in: D.FUCHS, H.-D.KLINGEMANN(eds), Culturaldiversity, Europeanidentity and the legitimacy of the EU, Ed. Elgar Publishing Ltd., Cheltenham, 2011, pp.61-85; W. LOTH, EuropäischeIdentitätin historischer Perspektive, Zentrum füreuropäischeIntegrationsforschung,ZEI Discussion paper C 113, 2002; W. KNELANGEN, Die EU und der Vertrauensverlust der Bürgerinnen und Bürger, in: Aus Politik und Zeitgeschichte, 4(2012), pp.32-40.

3. Cf. as particularly important, more recent historical overviews of European integration: M.-T.BITSCH, Histoire de la construction européenne, Éd. Complexe, Paris, 2004; A. BLAIR, The European Union since 1945, Pearson Education, Harlow, 2005; G. BOSSUAT, Histoire de l'Union européenne, Belin, Paris, 2009; B. BRUNETEAU, Histoire de l'unification européenne, Armand Colin, Paris, 2005; G. BRUNN,Die EuropäscheEinigungvon 1945 bisheute, Reclam Verlag, Stuttgart, 20092; G.CLEMENS, A.REINFELDT,G.WILLE, GeschichtedereuropäischenIntegration, Schöningh, Paderborn, 2008;D. DINAN, Europe Recast. A history of the European Union, Palgrave Macmillan, Basingstoke, 2004; J. DÜLFFER, Europa im Ost-West-Konflikt, Oldenbourg, Munich, 2004; J.EVERT, Die europäische Integration, Wissenschaftliche Buchgesellschaft, Darmstadt, 2006; J. GILLINGHAM, European integration 1950-2003: Superstate or new market economy?, Cambridge University Press, Cambridge, 2003; F. KNIPPING, Rom, 25. März 1957. Die Einigung Europas, Dtv, Munich, 2004; W. LOTH, Der Weg nach Europa: Geschichte der europäischen Integration 1939-1957, Vandenhoeck \& Ruprecht, Göttingen, 1996; J. MITTAG, Kleine Geschichte der Europäischen Union. Von der Europaidee bis zur Gegenwart, Aschendorff Verlag, Münster, 2008; B. OLIVI, A. GIACONE, L'Europe difficile; histoire politique de la communauté européenne, Folio, Paris, 2007; H.-J. SEELER, Geschichte und Politikder europäischen Integration, Nomos, Baden-Baden, 2008; P. STIRK, A history of European integration since 1914, Pinter Publishers, London 2001; G. THIEMEYER, Europäische Integration. Motive-Prozesse - Strukturen, Böhlau, Cologne, 2010; W. WESSELS, Das politische System der Europäischen Union, VS Verlag für Sozialwissenschaften, Wiesbaden, 2008. 


\section{Crises of European Integration - A Typology}

The past crises of European integration are difficult to classify. Each and every crisis, including the recent one, possesses its own particular profile, its own contexts and also its own interpretation by contemporaries. Thus a typology for previous crises of European integration must be handled with caution; accordingly, it will limit itself to an inductive typology, which can merely account for these past crises and does not seek to develop a theory for treating future crisis.

A clear and workable definition of the crises of European integration is a prerequisite for such a typology. What exactly crises of European integration are meant to denote has not yet been determined. This particular article conceives of them as crises of political decision-making, rather than structural crises of the economy or culture. They were blockades affecting pivotal political decisions regarding European integration across the board, and not merely in one of the many fields of European policy. What is crucial about them is the fact that they were perceived as crises by contemporaries, rather than merely being classified as crises in hindsight by historians. Politicians came to face new challenges as a result of these crises, which demanded new responses. The crises of European integration were usually relatively self-contained events spanning only a few years, and were very rarely prolonged crisis situations. ${ }^{4}$

One can differentiate further. The extent and scope of each particular crisis stands as the focus of this classification scheme, for an incorporation of the causes and the solutions into this typology would have been too complex. Exactly how far-reaching the extent of a crisis was and the type it corresponded to mainly depended on three conditions: whether the blockade of decision-making remained confined to the governments of the member states or whether the national and European publics and civil societies also participated; whether these were purely political crises or whether they were interlaced with economic, social or cultural upheavals; whether the crisis was limited to Europe or whether non-European powers and publics were also involved in these conflicts. In order to avoid any misunderstandings, it must be noted that the following typology does not seek to suggest a historical development of sorts. Moreover, the typology merely accounts for the history of European integration since the 1950s. While a typology of crises of the international European system since the Middle Ages would certainly be interesting, it would most probably not contribute

4. The brilliant and often employed concept of crises developed by Reinhart Koselleck, who viewed crises as a consequence of public criticism in particular, can only be applied to Europe as a whole with much difficulty, partially because the development of the European public sphere and therefore critiques of European policies was weaker than in the European states since the $18^{\text {th }}$ century, but also because most intellectuals tended to confine their activities to their respective national public sphere, and because of the fact that it was not always entirely clear to whom this European public criticism could be addressed, given that the European Union's most powerful centre of decision making - the European Council - is comprised of the national heads of state who, as a general rule, are compelled to return into the fold of national politics and face their respective national publics following the decisions reached by the council. 
to our understanding of the current crisis and could only be developed by a group of historians with different areas of expertise.

A first type of crisis of European integration was mere crisis management. These were local crises, which emerged either within or outside the territory of the European Union and demanded crisis management by the European Union, however they usually did not develop into crises of European integration. This latter only occurred when the European Union faced a blockade of the decision making process, either because member states entered into irreconcilable conflicts with each other, or because the European Union did not possess the competences to resolve them. One example of crisis management that did not lead to a crisis of the European Union and thus does not feature in the list of crises of European integration was the military conflict between Georgia and Russia in 2008, during which the President of the European Council intervened and proposed a solution that helped in the ceasing of hostilities. Conversely, the civil war in Yugoslavia (1991-95) provides an example of how crisis management escalated to become a crisis of European integration. The European public expected the European Union to appear on the stage as an actor who would help provide a solution to this crisis. The war in Yugoslavia touched a sore spot in Europe's identity, as securing peace in Europe is a central component of European identity and this was the first time since World War II that a war was being waged on European soil. Given that the European Union does not possess its own military deployment force, however, it was unable to manage this crisis and ultimately failed. Thus the public also came to view the $\mathrm{Yu}-$ goslavia crisis as a crisis of European integration.

A second type of crisis was a diplomatic blockade of the decision-making process. This crisis was one of fundamental conflicts regarding European integration, however it was confined to the governments of member states and thus amounted to a purely diplomatic affair without massive participation by the media, the public or civil society. It was not accompanied by economic or cultural upheavals and was limited to the member states of the European Community or the European Union. This notwithstanding, it was perceived as a serious crisis by the governments involved. A prime example of this is to be found in the crisis of the empty chair (1965/66), a pivotal conflict between the governments of member states regarding the decision-making reforms of the European Economic Community, which had developed in the aftermath of de Gaulle's unilateral veto of Great Britain's application to the EEC in 1963 and which was further exacerbated by the unilateral French withdrawal from the military structures of NATO. In 1965/66 the French government under Charles de Gaulle rejected contractually designated majority decisions and discontinued its work in the European panels and committees. This fundamental conflict over the proceedings of the decision-making process was also perceived as a crisis by the governments of the member states.

A third type of crisis consisted of conflicts surrounding basic European decisions between governments and mobilised publics. In this type of crisis, blockades of decision-making did not merely arise between the governments of the European member states. The public sphere, the media, experts and civil society are also at odds over fundamental European decisions. While this type of crisis was also purely political and not 
accompanied by economic or cultural upheaval, remained confined to Europe, and did not feature non-European actors in a prominent role, it was nonetheless more than just a diplomatic affair. It mobilised the citizenry and the media. A first example is provided by the crisis surrounding the French parliament's no vote on the European Defence Community in 1954 (which envisaged the creation of a strongly integrated European army in a addition to a political union of the six governments belonging to the European Coal and Steel Community). This French no was merely the end-point of a crisis in which conflicting notions over the fundamental question regarding the military integration of Europe during the Cold War and during the French war in Indochina opposed each other. The treaty of the European Political Community was a difficult compromise that was only half-heartedly supported by several governments und ultimately failed due to the French government's dilatory handling of the treaty in the national assembly. Particularly the French public was profoundly agitated and deeply divided.

Another example for this type of crisis was the conflict within the European institutions in the wake of German reunification. A basic dissent arose between the European governments regarding German reunification and a reunited Germany in the European Community. The European media too were mobilised and deeply divided over the issue of German unification and Germany's inclusion in the European Community. This does not correspond entirely to this type because the decision regarding German unification lay mainly with the USA and the USSR. However, the decision regarding the subsequent development of European integration in the wake of German re-unification, i.e. the Treaty of Maastricht, was reached by the European governments alone. Another feature of this crisis was that the ratification of the Maastricht Treaty was in jeopardy because it had been rejected by Denmark following a referendum and a negative outcome was also expected from Great Britain. Not only the governments, but also the Danish and British public were massively involved in this act of the crisis. A third, slightly different example of this type of crisis was the rejection of the European Constitution following referenda in France and the Netherlands in 2005. While this constitutional treaty ultimately did materialise following a compromise that had been reached after intense consultations between the fifteen governments involved, the national publics were deeply divided over the issue. Public polls in most member states showed no clear majority. The close result of the French referendum mirrored this deep division within the European public sphere.

A fourth type of crisis consisted not only of decision-making blockades between the governments of the member states and deeply divided publics, but was also accompanied and influenced by simultaneous economic and cultural upheavals. In the public perception, the crises were not limited to European integration alone either, but were instead seen as more elaborate and extensive European crises. European governments and their publics found themselves confronted with a new economic, social or cultural situation and were forced to reconsider their basic self-conceptions and political concepts. The early 1970s were an example of this type of crisis, during which the high-flying European plans for an economic and currency union as well as a political union faltered and the Northern expansion of the European Community was rejected by Norway and viewed with scepticism by Great Britain. At the same time, Europe expe- 
rienced a profound economic upheaval, the end of the Bretton Woods currency system, the 1973 and 1979 oil crisis, the rapid and enduring decline in economic growth and, later, strong inflation. The mentalities too were subject to change, as optimistic visions of the future that underpinned the planning euphoria of the 1950s and 1960s began to subside and came to be supplanted by more sceptical notions of future development. These new economic and cultural conditions also led to fundamental changes with regard to European integration. A slow process of searching for solutions to the failed economic and currency union and the largely failed political union began. Unlike other crises of European integration, this particular crisis was a lengthy one, which seemed to have been overcome in the late 1970s following new steps towards integration such as direct elections for the European Parliament and the European currency system, yet broke out anew in the early 1980s in the wake of Eurosclerosis, the fact that the European economy was being outperformed by other Western economies, and new demands were being placed upon European integration.

A fifth type of crisis accounts for a decisive geographical dimension: the global crisis of decision-making. This type of crisis was not confined to Europe and did not only divide the governments and the publics of the member states, as the governments and the public sphere of non-European countries also came to be affected by this crisis, which often also led to divisions there. As a result, these countries also sought to bring their influence to bear on the European publics and the decision-making process. Particularly in cases when big non-European powers were involved, the nature of the crisis also changed for the Europeans. New notions of a common global mission, but also images of a crisis imposed and obtruded from the outside can emerge in this type of crisis. The crisis since 2010 broadly corresponds to this type of crisis. It was prompted by the international financial crisis, which originated in the USA in 2007. Within the unusually constructed European monetary system, from 2010 this financial crisis triggered a European debt crisis, extremely high interest rates for government bonds of the Southern member states, and growing scepticism towards the European currency system, which not only placed a strain on the European economy but also the non-European economies. It forced preparations for further steps towards integration, for tighter European controls over national budgets and the European banking system. This crisis was also perceived as a particularly serious one in the European media and among experts. Given that this debt crisis and its solution through the efforts of the European Union also affected the USA, China, India and many other countries, not only the governments of the big powers, but also the International Monetary Fund, the G20 and international experts sought to influence the decisions of the Europeans.

A sixth type of crisis was the civilisational crisis, the variant of crises of European integration. It was not simply a decision-making blockade of the European governments, nor was it merely a deep division within the European media and its expert communities, or linked to an economic or cultural upheaval. It was more akin to a fundamental crisis of the entire economic and political system - a far-reaching erosion of society and culture that threatened to lead to the dissolution of political and social values and even the existence of Europe in and of itself. In this kind of crisis, a civilisation is usually subdued by outside powers or at least incorporated into their 
sphere of influence. The only example of such a crisis in recent European history was the immediate period after the end of the Second World War, during which millions of families lamented for the dead and the disabled, many European cities had been destroyed, millions of Europeans lived on the streets without hope, many had no income, no food and no accommodation. Europe was engulfed in deep pessimism, divided and assigned to the Soviet empire or the hegemony of the USA. This European civilisational crisis was simultaneously also a crisis of European integration. Indeed, it gave rise to many ideas and several attempts to further European integration, which nonetheless quickly entered a crisis again and sank into insignificance or marginality.

\section{Which History: Ever More Acute Crises, Crisis Cycles or Productive Crises?}

This typifying overview of the crises of European integration better allows us to pursue the question of which of the abovementioned interpretations best subsumes the developments of the past six decades: the notion of catastrophe, which sees ever more serious crises culminating in the collapse of European integration in the not too distant future, the notion of crisis cycles, which posits that each new generation experiences the crisis of European policies of the older generation and comes to develop its own new policies, or the conception of productive crises, which prompts a further step towards European integration yet also requires all the fears and fantasies of collapse associated with a crisis as a means of building up the political pressure necessary for the next step towards integration.

The past crises of European integration are not indicative of the catastrophe scenario. Europe's gravest crisis, the crisis after the Second World War, did not occur at the alleged end, but rather at the beginning of the history of European integration. Even this crisis was not a mortal blow, however. In fact, it is rather astounding how politicians and intellectuals seized the initiative in the midst of this deep material and moral depression to found European institutions. Four attempts were made towards European integration, of which most nevertheless failed to meet expectations. The post-war period was thus a mixture between a crisis and a point of departure for European integration: 1948 saw the creation of the OEEC, an economic European organisation for Western and Eastern Europe that was founded under the pressure of the USA. However, this organisation was rejected by the USSR following negotiations over its sphere of influence and was also mistrusted by the West-European governments. It merely functioned as a coordinating agency for the implementation of the Marshall Plan and was eventually transformed and expanded into the OECD. The Brussels Treaty Organisation also came to be established in 1948 by five West European countries as a model of integration during the Cold War to protect against renewed German aggression, yet it soon sank into obscurity following the creation of NATO in 1949.

That same year also saw the creation of the Council of Europe under the leadership of Great Britain, which incorporated the majority of West European countries whilst 
preserving their national sovereignty, pursued political and cultural aims and established the European Convention of Human Rights. However the Council of Europe failed to fulfil the expectations placed upon an economic and political European entity with the capability to act by important countries on the European continent. Thus 1951 saw the creation of the European Coal and Steel Community under the initiative of France, which incorporated the coalmining and steel industries of six continental European countries into a supranational organisation, and in this way sought to secure peace in Europe and create more prosperity by means of reciprocal control of the most important industries for arms production at the time. It was only during this fourth attempt that the precursory organisation to the European Union was created at the end of the post-war crisis.

While the crisis during the early 1970 s was also profound, it nonetheless possessed an entirely different character than the current crisis. It was not merely an economic and cultural crisis with the termination of the international Bretton Woods currency system by the US-government, the staggering spike in oil prices due to the oil crises, the dramatic decline of formerly high economic growth rates, insufferably high rates of inflation, the shift from Keynesian to monetarist economic policy and with all this, the retreat of optimistic planning schemes for the future. Beyond this, it was also a serious crisis of European integration, a deep disappointment following the failure of high-flying plans to build up a European political union, an economic and currency union and in the light of the difficulties encountered during Northern accession after the Norwegian no-vote and the conflicts arising from British membership. This crisis was so profound that it would take until 1979 for first new, incremental steps towards integration in the form of the European Monetary System (EMS) and direct elections for the European Parliament that were not accompanied by great success. It was not until the mid-1980s, with the Single European Act and the single market, that European integration eventually gained new momentum. When viewed against the backdrop of the serious post-war crisis and the crisis of the 1970s, the current crisis appears less unique in terms of its scope and extent.

Whether the notion of cyclical crises serves as a more accurate historical representation of the crises of European integration is debatable. Given that the history of crises of European integration is simply too short, it would be premature to draw the conclusion that these three crises were cyclical in nature. Furthermore, the crises that have occurred in the past are too dissimilar to favour a cyclical interpretation. While the first of these three crises was wholly determined by the aftermath of the Second World War, neither of the two other crises was directly war-related. Whereas the crisis of the 1970s was rooted in a failure of new European projects, the current third serious crisis is essentially a crisis revolving around the defence and reform of the Euro. Moreover, these crises cannot really be interpreted as a newer generation's takeover of European policy. The founding fathers who faced the post-war crisis were all elderly men who sought to expurgate the European project that had been advanced by one of their contemporaries, Adolf Hitler, and his vision of National Socialist domination over Europe. During the 1970s, however, the projects of a new generation - of Willy Brandt, Georges Pompidou, Leo Tindemans and Pierre Werner - may have failed, but this was not a failure of 
the projects pursued by those of previous generations. Indeed, while one might be inclined to view the current crisis as the fatal legacy of a poorly constructed currency system promoted by the generation of Helmut Kohl and François Mitterrand, it still remains unclear whether a younger generation of EU politicians will succeed in formulating and establishing a new and viable concept of European unity.

The third concept, namely that of productive crises, which posits a progression towards European integration in regular intervals, serves as the most accurate depiction of historical realities, however not without some limitations. Critics of this concept tend to cite three main arguments against such an interpretation.

First, while crises eventually did come to an end, they were not necessarily resolved in every case. It is worth pointing out two examples of such non-productive crises. According to some textbooks, the crisis in the wake of the French national assembly's rejection of the European Defence Community project in 1954 had been resolved as early as 1957 following the establishment of the European Economic Community. In actual fact, however, European military integration failed permanently in 1954. An integrated European army does not exist to this day, despite the progress under the CSDP. Instead, European armies were incorporated into NATO under the leadership of the United States. European policy was forced into a change of strategy amidst the crisis of 1954 and proceeded to place particular emphasis on economic integration rather than military and political integration in the decades that followed. The crisis of the empty chair in 1965/66 is often cited as yet another example of a similarly unresolved crisis. Indeed, it had officially been overcome following the Luxembourg Compromise. However, rather than being productive, this controversial compromise excluded the prospect of majority-backed decisions among the European heads of state for many years to come and instead continued to adhere to more ponderous decision-making procedures.

Furthermore, the notion of productive crises of European integration is often criticized because of the circumstance that the seemingly productive solutions of these past crises often carried within them deficits that would eventually come to provoke the next crisis. ${ }^{5}$ The crisis following German unification in 1990 - which is often cited as an example in the debate surrounding the current crisis - was resolved by the Maastricht Treaty and a stronger integration of Germany into the European economy through the creation of the Euro as a common currency in particular. However, this solution contained a grievous shortcoming: the new currency lacked the foundation

5. See the historical studies of structural deficits leading to crises: A. VARSORI, Les défis de l'Europe sociale, in: M.-T. BITSCH (ed.), Cinquante ans de traité de Rome ..., op.cit., pp.185-201; B. STRATH, Die enttäuschte Hoffnung aufdas soziale Europa, in: A. BAUERKÄMPER, H. KAELBLE (eds), Gesellschaft in der europäischen Integration seit den 1950er Jahren. Migration - Konsum Sozialpolitik - Repräsentationen, Franz Steiner Verlag, Stuttgart, pp.23-42; M. HALLER, Die europäische Integration als Elitenprozess. Das Ende eines Traums?, VS Verlag für Sozialwissenschaften, Wiesbaden, 2009; S. HIX, What's Wrong with the European Union and How to Fix It, Polity Press, Cambridge, 2008; G. THIEMEYER, Die Ursachen des Demokratiedefizits der Europäischen Union aus geschichtswissenschaftlicher Perspektive, in: W. LOTH (ed.), Das europäische Projekt zu Beginn des 21.Jahrhunderts, Leske und Budrich Verlag, Opladen 2001, pp.27-47. 
of an integrated financial and economic union and European control over the national budgets of member states and the banking sector in particular. This deficit proved to be among the most decisive of factors in the lead-up to the current debt crisis since 2010. ${ }^{6}$ Another example: the crisis in the wake of the failure of political union during the early 1970s was followed by attempts to resolve it in several incremental steps. Among these steps was the introduction of direct elections for the European Parliament in 1979. Yet these direct elections had an critical flaw, namely that, unlike most other national parliaments, the European Parliament could not elect a government of its own choosing. Thus the European electorate was not presented with a clear choice between different teams of representatives in these elections. As a result, voter participation progressively declined, and the European electorate became increasingly estranged from European politics. This estrangement was an important reason behind the ratification crisis over the Maastricht Treaty in 1992 and the crisis encountered during the ratification process of the European Constitution in 2005. ${ }^{7}$

Furthermore, the concept of productive crises possesses a third significant weakness: It is often used to postulate that these crises led to changes in political strategies and further steps towards European integration in and of themselves. This weakness may have something to do with an inclination to think in terms of crisis and refinement, a mode of thought with deep historical roots in the European tradition. Yet this concept overlooks the fact that there were always specific preconditions for a productive outcome of particular crises in the history of European integration that made it possible to find solutions to these crises in the first place. There were at least five permanent preconditions that effectively represent forms of continuity in the European crises of the past six decades, even though their role in each of these crises varied and despite the fact that they were seriously put to the test during the current crisis.

6. Cf. for example: H. ENDERLEIN, Krise in der Eurozone, in: Aus Politik und Zeitgeschichte, 42(2010), pp.7-12; W. STREEK, Gekaufte Zeit. Die vertagte Krise des demokratischen Kapitalismus, Suhrkamp Verlag, Berlin, 2013; W. ABELSHAUSER, It's not the economy, stupid. Die politischen Ökonomie der europäischen Integration in der Krise, in: Zeitschrift für Staats- und Europawissenschaften, 1(2010, pp.1-23; U. LAPPENKÜPER, Mitterrand und Deutschland. Die enträtselte Sphinx, Oldenbourg, Munich, 2011; T. SCHABERT, Wie Weltgeschichte gemacht wird-Frankreich und die deutsche Einheit, Klett-Cotta, Stuttgart, 2002; M. VAÏSSE, C. WENKEL, La diplomatie française face à l'unification allemande, Éd. Tallandier, Paris, 2011.

7. For broader research on Euroscepticism: J.T. ChECKEL, P.J. KATZENSTEIN (eds), European identity, Cambridge University Press, Cambridge, 2009; R.C. EICHENBERG, R.J. DALTON,op.cit., pp.128-152; D. FUCHS et al.(eds), Euroscepticism. Images of Europe among mass and political elites, Barbara Budrich Publishers, Opladen 2009; V. KAINA, Wir in Europa. Kollektive Identität und Demokratie in der Europäischen Union, VS Verlag für Sozialwissenschaften, Wiesbaden, 2009; W. KNELANGEN, Die EU und der Vertrauensverlust der Bürgerinnen und Bürger, in: Aus Politik und Zeitgeschichte, 4(2012), pp.32-40; A. SZCZERBIAK, P.A. TAGGART, Opposing Europe? The comparative politics of euroscepiticism, Oxford University Press, Oxford, 2008; S. WESKE, Europapolitik im Widerspruch. Die Kluft zwischen Regierenden und Regierten, VS Verlag für Sozialwissenschaften, Wiesbaden, 2011; B. WESSELS, Spielarten des Euroskeptizismus, in: F. DECKER, M. HÖRETH (eds), Die Verfassung Europas. Perspektiven des Integrationsprojekts, VS Verlag für Sozialwissenschaften, Wiesbaden 2009; S. VOGLRIEDER, Europäische Identität und Europäische Union: Das Selbst-und Europaverständnis der EU im Kontext der Vertiefungs-/Erweiterungsdebatte, in: W. LOTH (ed.), Das europäische Projekt ..., op.cit., pp.175-202. 
1) A consistent majority of European citizens held the view that European integration was a positive project. To be sure, the overall levels of support certainly varied greatly from state to state and changed significantly during the course of the history of European integration. Yet even in times of crisis, the supporters always outnumbered the opponents in the European Union as a whole, albeit only by a slim margin during the current crisis. ${ }^{8}$ The level of expectations foisted upon the European Union remained high, even in times of crisis and in reputedly sceptical countries. In the current crisis too, the expectations of a great majority of Europeans were considerable, particularly in the areas of foreign policy, security, environmental policy, counterterrorism and immigration, but also economic and monetary policy - expectations that tended to be greater than those levelled at the national member states. ${ }^{9}$

2) Moreover, unbeknownst to the often ritualized critiques of the EU by some politicians, European integration enjoyed a broad base of support among the majority of political elites, politicians and high-ranking officials, experts, journalists and intellectuals, interest groups and civil societies. The past decades were also marked by a continual expansion of the circles of political elites involved in the preparation or implementation of European decisions, the search for compromises, administrative tasks or public discussions. International networking among the elites grew both in scope and density. These elite networks were instrumental in bridging the divide of interests within Europe.

3) The long-attuned Franco-German partnership tended to be of considerable significance for decision-making during the crises of European integration. Indeed, it changed profoundly over the course of the past six decades: more open for a certain period, intermittently more exclusive, interspersed with periods fraught with tension and times of revived co-operation. Its strength did not merely lie in the sheer size of both countries and the lack of political alternatives to this bilateral partnership and leadership. France and Germany were often compelled to work out compromises over strongly diverging interests, and precisely these difficult compromises could serve as an important frame of reference for other member states of the European Union.

4) The enduring gravitational pull emanating from the EU as a field of action for national politicians, experts and intellectuals, which did not simply rest on the funds redistributed by the Union, but also on the global political influence of the European Union in which national politicians were able to partake, but also the potential chances to tackle problems for which there was no truly workable solution within the confines of national politics, such as security, the environment, energy, crime, migration, consumer protection or educational standards. Beyond this, there was not just the fear regarding the inestimable and potentially dangerous consequences in the event of a dissolution or disempowerment of the European Union, but also the possibility of passing the buck on to the EU for erroneous political decisions in one's own country.

8. Eurobarometer 79, spring 2013, p.10, Annex table 46.

9. For recent polling results: Eurobarometer 75, Autumn 2011, pp.67-77. 
5) Finally, despite all deficiencies and wrong decisions, the EU could nonetheless point out a whole range of accomplishments to its citizens and elites. It not only spurred on economic integration between member states, which did much to banish the looming threat of a return to the economic misery of the interwar period, but also managed to achieve more than a single small or medium-sized state in the abovementioned international policy fields. It made it possible for Europeans to safeguard their global influence without reverting to costly imperial projects claiming countless lives. Moreover, it was the only institution truly capable of securing democracy and peace in Europe.

If we refine the concept of productive crises to account for these three limitations, this qualified form would provide the most accurate historical representation of the crises of European integration, at least when compared to the other two concepts. This notwithstanding, it remains to be seen whether this concept, which corresponds rather closely to the realities of the past, will continue to bear relevance for the future of European integration.

One might assume a certain proclivity between these conclusions and neo-functionalist approaches. However, major differences exist. This article concludes that there was no autonomic route from crisis to additional supranational power of the European Union. Some crisis went in the opposite direction. Moreover functionalist approaches underestimate the importance of political decisions and political actors which do not necessarily follow the neo-functionalist concept. Finally functionalist theories do not take into account the particularly favourable conditions for regional integration in Europe since the late 1940's. In fact a major question to the historian is how these favourable conditions came into being and how they might be threatened. ${ }^{10}$

10. Translated from German by Ivo Komljen. The German Original edition of the present contribution was first published under the title Spirale nach unten oder produktive Krisen? Die Geschichte der Entscheidungskrisen der europäischen Integration in: Integration, 3(2013), pp.169-182. 
